\title{
THE DIAGNOSTIC CHALLANGE OF AN UTERINE MASS: UTERINE LYMPHOMA
}

\author{
Aysen Telce BOZA ${ }^{1}$, Evrim BOSTANCI ${ }^{1}$, Nermin KOC $^{2}$, Semih TUGRUL ${ }^{3}$, Selcuk AYAS ${ }^{1}$ \\ 1 Department of Gynecology, Zeynep Kamil Training and Research Hospital, Istanbul, Turkey \\ 2 Department of Pathology, Zeynep Kamil Training and Research Hospital, Istanbul, Turkey \\ 3 Department of Perinatology, Zeynep Kamil Training and Research Hospital, Istanbul, Turkey
}

\begin{abstract}
SUMMARY
Background: Lymphoma of primary genital tract is uncommon. The similarity of its symptoms (vaginal bleeding, pelvic pain,etc..) with other genital system diseases, presence of nonspesific symptoms on histologic and imaging examinations may make the diagnosis delayed and may cause overtreatment.

Case report: A-62 years old woman presented with postmenoposal bleeding. All the imaging studies [transvaginal ultrasonography (USG), Doppler USG, magnetic resonance imaging (MRI)] showed only enlarged uterus with a mass lesion orginated from uterine wall. The histopathologic analysis of fractionated cervical and uterine curettage were not diagnostic for postmenoposal bleeding and uterine mass lesion. To clarify the diagnosis, total abdominal hysterectomy (TAH), bilateral salpingooferectomy (BSO), peritoneal cytology sampling and frozen were carried out. While the frozen was reported in favour of malign pathology, the operation was continued with bilateral pelvic and paraaortic lymph node dissection (BPPLND) and omentectomy.

Routine pathology demonstrated diffuse large B cell lymphoma infiltrating myometrial wall. Bone marrow examination was normal. Flourodeoxyglucose positron emission tomography / computered tomography (FDG-PET/CT) showed no FDG-avid area in favour of lymphoma on whole body scan. She was considered as primary uterine lymphoma and received rituximab, cyclophosphamide, ,adriamycin, vincristine ve prednisolone ( $R$-CHOP) chemotherapy by hematology clinical follow up. She remains in complete clinical and radiological remission 6 months after the treatment.

Conclusion: Lymphoma of genital tract should be kept in mind in the case of difficulty to clarify the differential diagnosis of uterine bleeding or mass. Especially if uterine lymphoma infiltrated to the uterine wall deeply, preoperative histological analysis could not reveal the real pathology
\end{abstract}

Key words: diffuse large B cell lymphoma, primary malign lymphoma, uterus

Journal of Turkish Society of Obstetrics and Gynecology, (J Turk Soc Obstet Gynecol), 2014; Vol: 11, Issue: 1, Pages: 59-63

Address for Correspondence: Ayşen Telce Boza. Zeynep Kamil Eğitim ve Araştırma Hastanesi, Jinekoloji Kliniği, İstanbul

Phone: + 90 (530) 9230046

e-mail: arcke83@gmail.com

Received: 05 May 2013, revised: 13 June 2013, accepted: 13 June 2013, online publication: 15 June 2013 


\section{PREOPERATIF TANI GÜÇLÜĞ̈̈ YARATAN UTERİN KİTLE: PRİMER UTERİN LENFOMA}

\section{ÖZET}

Giriş: Kadın genital sisteminin primer lenfoması oldukça nadirdir. Primer uterin lenfoma, genital sistemin diğer hastalıklarıyla benzer bulgular ( vajinal kanama, pelvik ăgrı vs) vermesi, doku örneklemeleri ve görüntüleme tetkiklerinde de spesifik bulgular vermemesi ayırıcı tanıda yer alamamasına ve tanıda gecikmelere, ayrıca lüzumsuz cerrahi yaklaşımlara neden olabilmektedir.

Olgu: 62 yaşındaki hasta postmenopozal vajinal kanama şikayetiyle başvurdu. Uygulanan laboratuvar ve görüntüleme yöntemlerinde [transvajinal ultrasonografi (USG), Doppler USG, manyetik rezonans görüntüleme (MRG)] uterus boyutunda artış ve uterin duvar kaynaklı kitle dışında bulgu tespit edilemedi. Uygulanan endoservikal küretaj ve endometrial örneklemenin histopatolojik inceleme sonucunun postmenopozal kanama ve uterin kitleyi açıklayıcı olmaması nedeni ile hastaya total abdominal histerektomi (TAH), bilateral salpingooferektomi (BSO), batın yıkama sıvısı alınması uyguland, operasyon sırasında frozen sonucunun malign olarak bildirilmesi üzerine operasyona bilateral pelvik ve paraaortik lenfadenektomi (BPPLND) ve omentektomi eklendi.

Nihai patolojinin diffüz büyük B hücreli lenfoma olarak raporlanması üzerine hastaya kemik iliği biyopsisi yapılmış, sonucu da lenfoma infiltrasyonu saptanmayan normoselüler kemik iliği olarak raporlanmıştır. Florodeoksiglukoz pozitron emisyon tomografi/ bilgisayarlı tomografi (FDG-PET/BT) 'sinde tüm vücutta lenfoma lehine herhangi bir tutulum saptanmaması üzerine primer uterin lenfoma tanisı konulan hasta hematoloji takibinde rituximab, siklofosfamid, adriamisin, vinkristin ve prednison (R-CHOP) kemoterapisi almıştır. Kemoterapi sonrası 6 aylık takibinde tam bir klinik ve radyolojik cevap saptandl.

Sonuç: Preoperatif dönemde tanısı konulamayan uterin kanamaların veya kitlelerin ayırıcı tanısında primer genital lenfomalar akılda tutulmalıdır. Uterus kaynaklı lenfomada kitle uterin duvar içinde yerleșimli ise preoperatif histolojik tanıda güçlüklerle karşılaşılabilinir.

Anahtar kelimeler: diffüz büyük B hücreli lenfoma, primer malign lenfoma, uterus

Türk Jinekoloji ve Obstetrik Derneği Dergisi, (J Turk Soc Obstet Gynecol), 2014; Cilt: 11, Sayl: 1, Sayfa: 59-63

\section{INTRODUCTION}

Approximately $1 / 4$ of malign lymphomas originate from extranodal areas, mostly gastrointestinal system and $\operatorname{skin}^{(1,2)}$. Female genitalia is seen rarely in extranodal lymphoma involvement, even involvement secondary to disseminated disease is more common. Primary genital system lymphomas constitute approximately $\% 1,5$ of extranodal lymphomas ${ }^{(1)}$. Most commonly seen primary genital system lymphoma is diffuse large B cell non-hodgkin lymphoma (NHL) ${ }^{(4,5)}$. Average age at diagnosis is 55(35-67y) ${ }^{(6,7)}$. Vaginal bleeding is the most common symptom of those seen in cervix and vagina; but symptoms related to obstructive effect of the mass can be seen (pelvic pain, urinary obstruction, etc) ${ }^{(6,8)}$.

So we want to discuss this case having prediagnosis of uterine intramural mass, which we could not diagnose properly preoperatively, and focus on symptoms of primary genital lymphoms during diagnosis.
CASE

62 year old postmenoposal woman presented with complaining about postmenoposal bleeding ongoing for a month. In pelvic examination of the patient, who defined last menstrual period as 10 years ago, cervix was intact, uterus was of 12 weeks pregnancy in size and there was no palpable mass in bilateral adnexial area.

With transvaginal doppler ultrasonography, uterine size was measured as 127 x 87 x $56 \mathrm{~mm}$ and in corpus uteri, hypoechogenic, centrally hypervascular solid multiple mass, of which largest was 64 x $50 \mathrm{~mm}$ in size was found. Histopathological correlation of these structures was advised.

Also endometrial lining thickness was 5,7 mm and in uterine cavity ovoidal in shape, echogenic, polipoidal, $13 \mathrm{~mm}$ in diameter lesion was seen, bilateral ovarias were noted as intact.

Tumor markers were found in normal ranges as follows: 
CA-125 (cancer antigen-125): $12 \mathrm{U} / \mathrm{ml}, \mathrm{CEA}$ (carcinoembryonic antigen): 1,5 ng//ml, CA 19-9 (cancer antigen 19-9): 21U/ml, CA 15-3 (cancerantigen 15-3): $6 \mathrm{U} / \mathrm{ml}$. In magnetic resonance imaging, myometrial layer diffuse signal intensity discrimination was not clear and myometrial contour had lobulations which was $66 \times 48 \mathrm{~mm}$ in largest diameter and it was reported that sarcoma or lymphoma should be considered in differential diagnosis(Figure 1).

The pathology results of endometrial sampling which was performed following postmenoposal bleeding was reported as endometrial polyp and endocervical results yield endocervical epithelium fragments. Conventional pap smear results were defined as negative for intraepithelial lesion or malignancy according to Bethesda system ${ }^{(9)}$.

In light of this data to clarify the diagnosis, total abdominal hysterectomy (TAH), bilateral salpingooferectomy (BSO), peritoneal cytology sampling and frozen were carried out. During operation, while the frozen was reported in favour of malign pathology, the operation was continued with bilateral pelvic and paraaortic lymph node dissection (BPPLND) and omentectomy

In macroscopic pathological investigation, surgical margins were intact in cervix and in cervical and myometrial cross sectional samples, locally united seperately placed yellow colored nodules were found (Figure 2a).

In cross sectional sampling of yellow colored tumoral nodules, endometrial and cervical surface epithelium was regular, diffuse atypical lymphoid cellular proliferation was seen which had main mass on myometrial and cervical wall, infiltrating myometrium in full thickness without expanding surgical borders and infiltrating endometrial stroma locally (Figure 2b) With immunohistochemical study, these cells were shown as positive for CD 45 cytoplasmic dye and for CD 20, bcl -2 , bcl $-6, \mathrm{Ki}-67$ and negative for CD 3.

With Real/WHO classification depending on histopathological and immunohistochemical investigation it was defined as NHL diffuse large B cell type ${ }^{(10)}$.

It was shown that bilateral tuba uterina and ovaries were intact and in lymph node dissection 4 out of 32 , which were in left pelvic area, lymphoma infiltration was seen and no atypical cell defined in abdominal wash fluid.

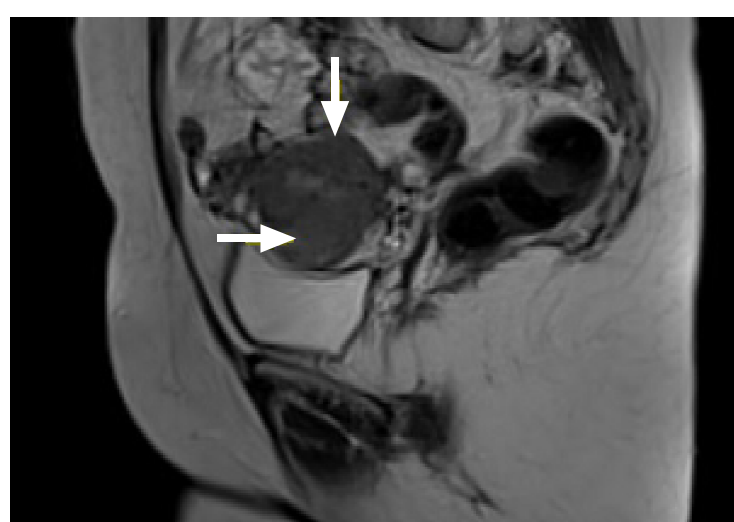

Figure 1: Lobulations in myomterium are shown by arrows.

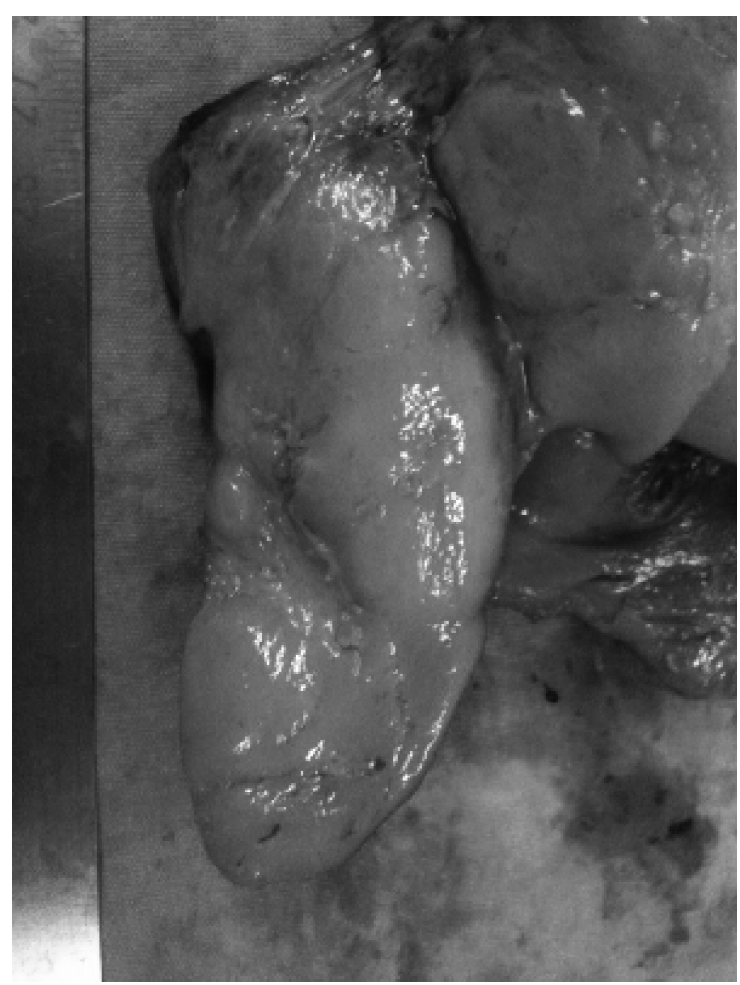

Figure 2a: Diffuse yellow colored tumoral nodules infiltrating full thickness of endometrium an myometrium.

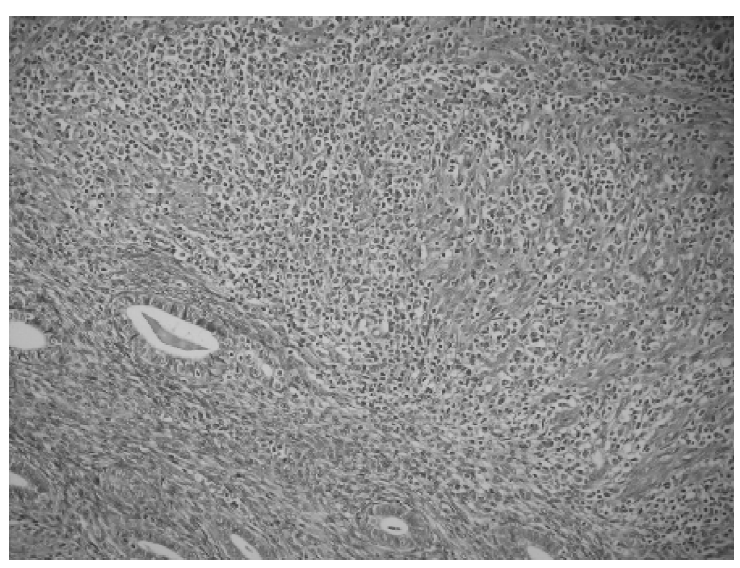

Figure 2b: (HE, X200) Atypical lymphoid cell infiltration, invasing endometrium and stroma. 
In order to differentiate nodal/extranodal lymphoma, flourodeoxyglucose positron emission tomography / computered tomography (FDG-PET/CT) was performed and showed FDG-avid area in favour of lymphoma on whole body scan, in pelvis around operation area, fluid collection which is $120 \times 92 \mathrm{~mm}$ in size, deplasing bladder superolaterally, resembling lymphocele and having no metabolic activity was seen. Bone marrow biopsy results were as normocellular bone marrow without lymphoma inflitration. With the help of this data, as there is only one extralymphatic organ involvement and no B symptoms (night sweating, fever, weight loss) seen in $\% 40$ of lymphomas she was considered as primary uterine lymphoma, grade $1 \mathrm{E}$ according to Ann Arbour classification and received 3 times rituximab, cyclophosphamide, adriamycin, vincristine ve prednisolone (R-CHOP) chemotherapy by hematology clinical follow up ${ }^{(11,12)}$. After 6 months follow up of chemotherapy full clinical and radyological cure was seen. Before publishing this case report informed concent was done.

\section{DISCUSSION}

According to literature, vaginal bleeding is generally the presenting sign of most of cases diagnosed as primary uterine lymphoma. Despite the fact that diagnosis generally depends on biopsy, small pieces of sampling may not be adequate to define the lesion (13). In uterine lymphomas with cervical involvement, the diagnosis could be possible by punch biopsy, endocervical sampling or conization(14).

In this case presenting sign was vaginal bleeding. However preoperative biopsy sampling was not adequate for diagnosis because tumour was deep in myometrium(13).

According to MRI examination of 4 cases in literature, common properties of uterine lymphomas were being large masses having homogenous signal intensity and multinodular enlargement pattern ${ }^{(15)}$. In our case masses causing dissapperance of boundary between myometrium and endometrium and showing lobulation was seen and thought as sarcoma radiologically for the initial diagnosis. For our case and similar cases (intramurally located masses), the most powerful preoperative diagnostic tool would be MRI.

According to USG and MRI examinations showing mass in myometrium, tissue sampling figuring out malignancy, frozen section results concerning malignancy during operation, this case is defined as primary uterine malignancy anf staging laparatomy is carried out. As seen in this case also, in lymphomas unrelated to endometrium, having no cervical involvement biopsy results would be unconclusive, in such cases staging performed would not change survival rate and even may worsen life quality by increasing morbidity.

According to limited literature primary uterine lymphomas could be managed by TAH BSO, chemotherapy, radiation treatment or combination of both $^{(4)}$. Depending on published litareture, 3 diagnostic criteria are defined for primary uterine lymphomas, 1) tumour is clinically limited to uterus, 2) no atypical cells in periferal vasculature and bone marrow, 3) presence of at least a few months between genital system lymphomas and secondary involvements ${ }^{(16,17)}$. Considering all these criteria mentioned above support that this case could be diagnosed as primary uterine lymphoma due to tumour limited to uterus in imaging examinations, bone marrow biopsy incompatible with lymphoma, no secondary focus after 6 months of chemotherapy .

Retrospectively it could be concluded that, about $15,4 \%$ of lymphocyst appearance after gynecological staging surgery and morbidity due to operation would be a cause of more radical approach ${ }^{(18)}$. In future, it would be possible to apply more conservative approach in similar cases as frozen techniques.

\section{REFERENCES}

1. Dursun P, Gultekin M, Bozdag G et al. Primary cervical lymphoma: report of two cases and review of the literatüre Gynecol Oncol 2005;98(3):484-9.

2. Cantu de Leon D, Perez Montiel D, Chanona Vilchis J.Primary malignant lymphoma of uterine cervix. Int J Gynecol Cancer 2006;16(2):923-7.

3. Agaoglu FY, Fayda M, Dizdar Y, Basaran M, Yazar A, Darendeliler E. Primary uterine lymphoma: case report and literature review. Aust N Z J Obstet Gynaecol 2005;45(1): $88-9$.

4. Shen CJ, Tsai EM, Tsai KB, Wu CH, Hsu SC. Primary T-cell lymphoma of the uterine corpus. Kaohsiung J Med Sci March 2007;23(3):138-40. 
5. Heeren JHM, Croonen AM, Pijnenborg JMA. Primary extranodal marginal zone B-cell lymphoma of the female genital tract: A case report and literature review. Int J Gyn Path 2008;27(2):243-6.

6. Russell Vang, L. Jeffrey Medeiros, Chul S. Ha, Michael Deavers. Non-Hodgkin's lymphomas involving the uterus: A clinicopathologic analysis of 26 cases. Mod Pathol 2000; 13(1):19-28.

7. Upanal N, Enjeti A. Primary lymphoma of the uterus and cervix: two case reports and review of the literature. Aust $\mathrm{N}$ Z J Obstet Gynaecol 2011;51(6):559-62.

8. Frey NV, Svoboda J, Andreadis C, Tsai DE, Schuster SJ, Elstrom R et al. Primary lymphomas of the cervix and uterus: the University of Pennsylvania's experience and a review of the literature. Leuk Lymphoma 2006;47(9):1894-901.

9. The 1988 Bethesda System for reporting cervical/vaginal cytological diagnosis. National Cancer Institute Workshop. JAMA 1989;262(7):931-4.

10. Swerdlow SH, Campo E, Harris NL et al. World Health Organization classification of tumours of haematopoietic and lymphoid tissues, (Eds), IARC Press, Lyon 2008.

11. Moormeier JA, Williams SF, Golomb HM. The staging of non-Hodgkin's lymphomas. Semin Oncol 1990;17(1):4350 .
12. Anderson T, Chabner BA, Young RC, Berard CW, Garvin AJ, Simon RM et al. Malignant lymphoma. 1. The histology and staging of 473 patients at the National Cancer Institute. Cancer 1982;50(12):2699-707.

13. Van Renterghem N,De Paepe P,Van den Broecke R, Bourgain C, Serreyn R. Primary lymphoma of the cervix uteri: a diagnostic challenge. Report of two cases and review of the literature. Eur J Gynaecol Oncol 2005;26(1):36-8.

14. Binesh F, Karimi zarchi M, Vahedian H, Rajabzadeh Y. Primary malignant lymphoma of the uterine cervix. BMJ Case Rep 2012 Sep 24;2012.

15. Goto N,Oishi-Tanaka Y, Tsunoda H, Yoshikawa H, Minami M: Magnetic resonance findings of primary uterine malignant lymphoma. Magn Reson Med Sci 2007;6(1):7-13.

16. Fox H, More JR: Primary malignant lymphoma of the uterus. J Clin Pathol 1965;18(6):723-8.

17. Fox H, Langley FA, Govan ADT, Shirley Hill A, Bennet MH. Malignant lymphoma presenting as an ovarian tumour: a clinicopathological analysis of 34 cases. Br J Obstet Gynaecol 1988;95(4):386-90.

18. Ghezzi F, Uccella S, Cromi A, Bogani G, Robba C, Serati M et al. Lymphoceles, lymphorrhea, and lymphedema after laparoscopic and open endometrial cancer staging. Ann Surg Oncol 2012;19(1):259-67. 